Article

\title{
Folklore and the Hebrew Bible: Interdisciplinary Engagement and New Directions
}

\author{
Susan Niditch \\ Department of Religion, Amherst College, Amherst, MA 01002, USA; sniditch@amherst.edu \\ Received: 16 November 2017; Accepted: 1 January 2018; Published: 10 January 2018
}

\begin{abstract}
This essay explores the rich interactions between the fields of folklore and biblical studies over the course of the 20th century until the present. The essay argues for the continued relevance of folklore and related fields to an appreciation of ancient Israelite cultures and their artistic inventions. It concludes with several case studies that underscore the fruitful realizations that emerge from this sort of interdisciplinary humanistic work.
\end{abstract}

Keywords: form-criticism; oral tradition; formula; morphology; typology; social context; performance

\section{Introduction}

The fields of biblical studies and folklore studies have always shared much in terms of content and methodology. Readers of the Hebrew Bible encounter narratives about the exploits of heroes and the creation of the world, they find descriptions of ritual actions rich in symbolic media, saying forms akin to proverbs and riddles, and verbal repetitions of various kinds betokening formulaic and traditional styles of speech-a corpus richly suggestive of folklore. Biblicists' interests in life settings, prosody, literary forms, reception, and redaction in many ways, moreover, parallel those of folklorists who emphasize performance contexts and cultural settings, the texture, content, and structures of various folk genres, the significance of these aspects of genre for an appreciation of message, and the importance of developments in stories and other media across time and place.

The scholarly interrelationship between the study of the Hebrew Bible and folklore studies has a long, complicated history. One thread in this work engages with the texture of biblical literature, questions about oral composition, oral-traditional style, and the implications of finding such evidence in biblical literature. Here the emphasis is on particular styles of repetition and formulicity and interest in the performance settings and occasions in which such works may have been created, shared with audiences, and preserved. Another related thread of study deals with content, that is motifs and recurring patterns within literature, whether narratives or other forms, and again with the implications of such forms for an appreciation of Israelite culture, contexts, and concerns. Scholars seek to understand what the Israelite composers' use of such types of content and patterns of content share with those of other cultures, and the resulting analysis has important and revealing humanistic and cross-cultural dimensions. A third thread comes under the heading of context and material culture, the study of things, the physical stuff of human interaction, and the study of non-verbal media. For biblicists, the findings of Near Eastern archaeologists, pots and statuary, burial sites and the remains of dwellings, monumental buildings and simple structures, contribute to the study of ancient Israelite cultures and worldviews as do biblical descriptions of physical and embodied behaviors in ritual processes and prophetic activity. In these ways, as with folklorists, scholars of the Hebrew Bible engage with "texture, text, and context" to use terminology offered by folklorist Alan Dundes (1980a, p. 20): style and choice of language; content and patterns of content; and setting and cultural location. 


\section{Folklore and the Bible: Past Trends and Contemporary Contributions}

One exciting early locus of this scholarly synergy between folklore studies and biblical studies is exemplified by the work of Hermann Gunkel and some of his contemporaries. Gunkel was especially attuned to the styles of biblical literature, for example, drawing thoughtful comparisons between tales of Jacob and those about Joseph, seeing the former as simpler folkloristic genres, phrase by phrase, and motif by motif, the latter as more sophisticated versions of traditional story-telling, with their interlocking more complex verbal constructions and plots (Gunkel 1966).

Gunkel was fully familiar with the work of the seminal German collectors of lore the Grimms and with that of Danish folklorist Axel Olrik who sought to describe typical traits of folk narrative (Gunkel 1966; Olrik 1965; Culley 1986, pp. 33-34). He was perhaps also aware of the sort of collecting and cataloging work that was being done by Finnish folklorist Antti Aarne whose catalog of international folk motifs was first published in 1910. This collection would be the basis for the extended compendia prepared by American folklorist Stith Thompson (Thompson 1955-1958; Reventlow 2010, pp. 346-47). ${ }^{1}$ Gunkel explicitly mentioned Anti Aarne's work in his Folktale in the Old Testament, originally published in 1917. He noted how a number of his colleagues in biblical studies including Edward Meyer, Hugo Winckler, Alfred Jeremias, Hugo Gressman, and Hans Schmidt drew useful comparisons between biblical motifs, forms, and attitudes and those found in an international fund of folklore (Gunkel 1987, pp. 33-34, 180, n. 1). Hans Schmidt, for example, explored folkloristic dimensions of the book of Jonah, with its runaway servant and its man-swallowing fish, allowing for cross-cultural examination of the biblical material and an appreciation of the ancient author's narrative techniques and the work's humanistic, story-telling nuances. In this way, Schmidt moved beyond the more typical theological preoccupations of biblical scholars (Schmidt 1907). This sort of study, employing the expanded Type and Motif Indices edited by Stith Thompson is found as well in more recent work, for example Niditch and Doran's (1990) study of the wise courtier motif or Dorothy Irvin's (1977) examination of motifs associated with the birth of a hero. Less neatly catalogued collections of relevant comparative material are found in Sir James George Frazer's monumental Golden Bough (Frazer 1911-1915) and biblicist Theodor Gaster's expansion of Frazer's treatment of biblical narrative content (Gaster 1981). Frazer and Gaster were interested in the ways that internationally recurring pieces of content relate to narrative patterns, the genesis of these patterns over time and place, and possible ritual practices. While many of these concerns are no longer the focus of biblicists, the work of the great cataloguers of early and mid-twentieth century nevertheless points to issues of content and structure, the various ways in which folklorists and biblicists have dealt with the categories of "text" and "context".

Modern scholars rightly criticize Gunkel for too often assuming that particular genres were associated with particular life settings, whereas literary forms have much more flexible applicabilities and settings. They note that he was wrong to suggest oral literature is always earlier than written, short and simple rather than long and complex, and criticize his romanticized and often condescending portrait of the "folk" audiences of such material (see Gunkel 1987, pp. 347, 349, 351, 353, 357; Niditch 1993, pp. 1-2, 7-9). His evolutionary view that material moves from oral to written achieving increasing cultural sophistication over time, moreover, interweaves with the essentials of source-criticism, perhaps distracting from the power of Gunkel's own observations and his capacity to reimagine ancient Israel. His interests in the aesthetics of this material within its settings nevertheless led to profound and seminal contributions to the study of biblical literature and the cultures of ancient Israel. His work alerts us to possible real people behind these texts, their lives, and concerns, and makes us think of this material as living and immediate. The texts, their form and content, are expressive of and capable of shaping actual human beings' worldviews.

1 Reventlow also emphasizes Gunkel's debt to Herder (pp. 346-47). 
Even allowing for Gunkel's respect for folklore studies and the implications of his comparative work, it is important to note that he was a bit embarrassed by the whole enterprise, normatively oversensitive, suggesting that there are no longer real folktales in the Hebrew Bible because of its heightened theological, truth-seeking concerns (Gunkel 1987, p. 33). Implicit normative concerns may also inform the work of Yair Zakovitch (1981) and Robert Alter (1990) who pay fine attention to the familiar traditional-style content and patterns of biblical literature and in the case of Alter to its use of repetition and delimited vocabulary so typical of oral-traditional material and yet who both insist that the Bible is not folklore.

A great generation of folklorists working in the second half of the 20th century further developed the field of folklore studies and the related study of early and oral literatures, often attempting to define both their field of study and its content. These scholars in turn influenced a raft of biblicists. The emphases, interests, and contributions of the folklorists and their various applications by biblical scholars again might be explored under the overlapping categories of texture, text, and context. Also worth keeping in mind is folklorist Dan Ben-Amos' description of folklore as "a kind of art", "a body of knowledge", and "a mode of thought" (Ben-Amos 1972, p. 50). We begin with matters of texture, ways, on a basic level of language, to describe the kind of art preserved by the Hebrew Bible.

Albert Lord and his teacher Milman Parry sought to understand how oral-traditional works are composed, under what conditions, and with what cultural implications (Lord 1968). Building on their work, John Miles Foley asked further and more deeply how orality relates to audience reception and participation, a shared culture that is metonymically invoked (Foley 1991). In collecting orally performed lore, Dennis Tedlock emphasized the need to demarcate caesuras, gestures, and various non-verbal aspects of the communicative event (Tedlock 1990). Dan Ben Amos also emphasized that ultimately folklore is not a thing, a text, a collectable, but, rather, real folklore is a communicative process, a performance (Ben-Amos 1972, p. 9), and of course were one to hold too rigidly to this definition, we would have to agree with Alter (1990) that the Hebrew Bible is not folklore. On the other hand, the folklorist Margaret Mills pointed to the "reoralization" of folklore-in the case of the Bible, to the myriad ways in which the biblical texts are reused in oral cultures and reinvented (Mills 1990). As in the case of Rabbinic midrash, portions of this rich trove of folklore may be written down and preserved, as the process from written to oral to written continues. Some such as socio-linguistics scholar Del Hymes (1981a, 1981b) are deeply interested in fact in the relationship between orally performed pieces and the form in which they are written down. How does the collector or redactor contribute to or alter the direction of the tradition? Similar questions arise in Grimm scholarship concerning the work of the brothers (Rölleke 1991; Zipes 1991). Are redactors actually composers who respond to oral-traditional expectations and habits? Do writers in particular cultures compose as if they were performing? So suggested Gregory Nagy (1996, p. 69) and A.N. Doane (1994) concerning written works that seem to reflect oral-traditional sensibilities and styles, those qualities of repetition and variation in language, content, and structure mentioned earlier. ${ }^{2}$ These questions, of course, are entirely relevant to dealing with the highly redacted and clearly now long-written down texts of Scripture which nevertheless exhibit qualities of oral literature.

Lord's work on the formula was especially influential in biblical studies. Lord and Parry defined the formula as a group of words used under certain metrical conditions to convey an essential idea (Lord 1968, p. 30). Taking account of a metrical component is difficult in working with biblical material. The literary tradition exhibits a wide range of poetic registers, and even material that is often considered to be prose exhibits qualities of oral-traditional literatures. Biblical scholar and translator Everett Fox (1995) has shown how the biblical text can be laid out in self-standing lines, like blank verse. The thought is complete at the end of the line even if the sentence continues. This style, which Lord called adding style (Lord 1968, p. 54), characterizes, for example, much of the biblical book

2 See also Katherine O’Brien O'Keeffe (1990). 
of Judges even though common translations set most of Judges up in prose paragraphs and do not emphasize the parallelistic repetitions between lines so common in what is usually assigned to the category of biblical poetry. In this way translations often fail to draw attention to the repetitions in syntax and terminology typical of traditional literatures.

While Robert Culley concentrated on possible formulicity in the biblical poetry of the Psalms (Culley 1967), David Gunn (1974) found formulicity in the phrasing of content in narrative type scenes, to borrow Alter's phrase (Alter 1981). William J. Urbrock (1976) looked for evidence of formulaic composition in Job and John R. Kselman (1978) in biblical material often attributed to "P", the Priestly Source, one of the underlying sources attributed to the Pentateuch in a lengthy tradition of biblical scholarship. More recently, Raymond Person has explored questions about variants, the ways in which one biblical writer seems aware of and employs a shared biblical literary tradition, not only its content but the language used to express it (Person 1998). Does the composer quote, copy, and develop an existing written text or does he share with predecessors in ancient Israel a way of telling particular stories, tales of the history of the people?

In the biblical tradition, there are ways to express a given idea or image. Moreover, these "ways" need not be exact repetitions, but more often are recognizable variations on formula patterns so that a recurring and recognizable syntax is filled in by any of a number of equivalent terms, readily available in ancient Israel from the rich collections of synonyms frequently employed in biblical examples of poetic parallelism (see Niditch 1996, pp. 8-24). For example, when a ruler is faced with a difficult to solve problem, whether in tales of Joseph and Pharaoh or Daniel and Nebuchadnezzar, he "calls to" advisors in a formulaic chain of possible aides such as counselors, magicians, sorcerers, or wise men, e.g., Gen 41:8; Dan 2:2. Another example is provided by the formula pattern related to the description of epic heroes (tribe + location + tenting/dwelling), found in the catalog of warriors in Judges 5:16-18 and elsewhere in the preserved tradition, e.g., Gen 16:12; 49:13. A formulaic description found at Ps 68:8-9 (Eng. 68:7-8) and Judges 5:4-5 captures the essence of the divine warrior, marching forward to battle in an earth-transforming, storm-producing way. The examples from Judges 5 and Psalm 68 point to traditional variation within the parameters of formula patterns (e.g., the deity may be called "God" or "Yahweh", he may march from the "open country of Edom" or from the "desert") and to formulas that share precisely the same words.

Such repetition and variation in language is not merely a matter of idiomatic speech or of quotation, but does seem to be a way to express a given idea, a style of composition to which Lord and Parry pointed. As Culley and the others concluded, however, such observations about an aesthetic that appreciates repetition and variation is not proof of oral composition. The style smacks of oral-traditional sensibilities rooted in an oral world, but such an aesthetic can reflect oral composition or the work of writers who are sensitive to such an aesthetic. Biblical scholar Robert Miller II (Miller 2011) has employed a balanced and thoughtful approach to oral composition and the possible contexts for such performance. In particular, he has engaged in comparative work, asking for example if Scandinavian traditional literature preserved in writing might illuminate the sort of compositional and contextual forces that lie behind biblical cases. In this respect, he has reprised and up-dated some of the work of early 20th century biblical scholars such as Ivan Engnell and Helmer Ringgren (Miller 2011, pp. 40, 85-113).

As in the case of Gunkel's work, caution is to be advised when observations about traditional style or texture are used to establish a relative chronology in Israelite literature, a point with which Robert Miller has agreed. An Israeli biblicist with interests in socio-linguistics, Frank Polak $(1998,2016)$ suggested that the simpler the syntax and the more obvious the adding style, the earlier the biblical composition. Again while his work is descriptively useful, its reliability for dating is questionable.

Two other contemporary scholars should be mentioned who have attended to oral traditional style with an eye to "how the Bible became a book", to use the title of one of their books. William Schniedewind (2004) and David M. Carr (2005) both began book length studies about the formation of the Hebrew Bible with consideration of oral-written interplays. Carr especially has been 
interested in the role of memory in the formation of biblical traditions. Despite the spontaneous or improvisational nature of oral compositions to which Lord pointed, memory clearly plays a significant role in the formation and preservation of traditional literatures. Carr also emphasized the "fluidity in scribal transmission of textual traditions" (Carr 2016a, p. 88), pointing implicitly to the use of writing in an oral world.

John M. Foley's emphasis on metonymy or "imminent art" (Foley 1991) has also influenced biblical scholarship by Niditch, Person, and others-the ways in which traditional literature is always engaging with cultural expectation for imagery and language so that a mere epithet, a color, or a single image can bring to bear on a scene as narrated a full and broad range of meaningful associations. An excellent biblical example is the epithet for the deity 'ăbîr ya'ăqōb found in Gen 49:24, Isa 49:26, Ps 132:2, 5 and often translated "the mighty one of Jacob". However, as shown by P. D. Miller (1970), the phrase more literally means the "bull of Jacob", a phrase that evokes the power of the horned male animal, warrior skills, youth, and fertility—hence the associations in other ancient Near Eastern mythologies between deities and bulls. This association explains the continuing attraction of bull iconographies in ancient Israel, a symbolic image condemned by dominant threads in Hebrew Bible, but nevertheless preserved not only in the epithet "Bull of Jacob", but also in other biblical references to "horns" in divine warrior contexts (e.g., Zechariah 2). Each time the epithet is used it brings to bear on the context the associations of the bull, even if the passage does not overtly deal, for instance, with Yahweh's victories in battle.

As noted, it is always difficult reliably to reconstruct the actual lived performance contexts for the textural phenomena discussed above or to assert that materials in Hebrew Bible were "originally" orally composed. Nevertheless, the biblical writers themselves do imagine performances, as Gunkel and others have noted: the delivery of prophetic oracles, reports of vision experiences, the performance of liturgy. Perhaps the most revealing biblical examples of folklore in context are scenes of proverb performance. The contributions of folklorists including Barbara Kirshenblatt-Gimblett (1973), Alan Dundes (1975, 1979), Wolfgang Mieder (2008), and Galit Hasan-Rokem (1990) have encouraged scholars of biblical wisdom literature to appreciate important aspects of the Bible as folklore.

In contrast to the encyclopedic collection of decontextualized sayings in the books of Proverbs and Ecclesiastes, the Israelite narrative tradition presents scenes in which characters deploy sayings of the topic/comment construction underscored by Dundes (1975) to offer oblique critique or address a social or political tension brewing between individuals or groups. An Israelite king facing battle with a potent enemy who threatens his people sends a message, "One who put on armor should not brag like one who takes it off" (1Kgs 20:11). As folklorists point out, this saying like others, can be contextualized in various ways, and intonation and gesture can affect meaning. The biblical framer of the tale of Saul thus employs the same proverb, "Is Saul too among the prophets?" in two contexts, one involving his rise and the other his decline (1 Sam 10:11; 19:24). The sayings about the armor and Saul could have be used by ancient Israelites apart from the specific biblical scenes created and contoured by the biblical writer and they might be re-oralized to apply to various social interactions. The scenes providing context may tell us something about the sayings' origins or may reveal stories that were created to accompany or explain preexisting sayings. Biblical scholars have also noted that the term $m \bar{a} \bar{s} \bar{a} l$, often translated "proverb", refers in the Hebrew Bible to a broad spectrum of forms that we might call proverbs or parables or icons or oracles. The study of biblical měšalîm is thus a reminder of Dan Ben-Amos' emphasis on "ethnic genres", for individual cultures or folk groups have their own local taxonomies of folk forms (Ben-Amos 1976; Niditch 1993, pp. 67-87). The study of biblical proverbs thus provides rich possibilities for fruitful interdisciplinary work in Hebrew Bible and folklore.

In addition to the textural interests that unite the study of the Hebrew Bible and folklore studies and the concerns with context that frame them, there exists a long history of work with the content and structure of folk media. Beginning this essay with references to ideas of the great Hermann Gunkel, we mentioned interests in recurring motifs and combinations of them that have occupied both 
folklorists and biblicists. Hermann Gunkel is the father of biblical form-criticism. Form critics try to delineate the content and structure of recurring biblical genres and further to make suggestions about the life settings and concerns that provided contexts for these communicative forms. With interests in prophetic speech and the psalms, Gunkel and those who followed in his footsteps outline the typical content of what were in their view originally speech acts, and then explore settings, for example, kinds of festivals, occasions for liturgy, or juridical procedures (Gunkel 1926; Tucker 1971). These basic interests in content and structure that relate to hypotheses about setting have much in common with important threads of folklore studies. A variety of structuralism and form-criticism is implicit in Stith Thompson's classificatory work that delineates and catalogs motifs and types of traditional narratives (Thompson 1955-1958, 1973). The motif is a small piece of tradition, a kind of character, or action, or special instrument, and the type is the narrative that combines these various motifs. In this way, Cinderella tale type 510 is composed of a persecuted heroine often associated with ashes, a magical helper, a recognition token such as the glass slipper and so on. Albert Lord's singers of tales similarly are shown to combine motifs into themes, a term Lord borrowed from music. For example, the return song of classical Greek and Serbo-Croatian epics consists of a group of themes which in turn are made of smaller motifs of content (Lord 1968, pp. 68-98). For Lord, knowledge of the recurring themes and motifs of the tradition combined with formulaic speech were keys to explaining the possibility of extemporaneous performance on the part of singers immersed in an oral culture in which composition and performance were one. For Stith Thompson, the delineation of types and motifs was a first step in tracing the development of tales, across geography and through time. He and his students searched for frequency of the lowest common denominator version of a tale and then felt that they could map its origins and development. Biblical scholars have tended not to try to trace the genesis of tales, but have found the availability of catalogs of types and motifs extraordinarily useful in exploring the nature of the literature itself, its meaning and messages. For example, some scholars tend to read the story of Gen 2-3 as "a fall", influenced by Christian interpretations of Eden, but, as discussed in more detail below, once one sees that stories about the coming of reality and the beginning of death are found in mythological traditions throughout the world, approaches can be less theological and more humanistic, less normatively tied to one religious orientation and more revealing of shared human concerns. The Type and Motif Indices also alert one to the over-historicization of tales among biblicists. If a battle is described in a similar way to battle accounts world-wide, perhaps it is best not to go try to identify the account as revealing military tactics that allowed a hero to succeed in that setting. The very existence of and accessibility of international variants moreover encourage the biblical scholar to appreciate biblical tales as Israelite versions of stories that are known in their essentials world-wide. For example, the flood story preserved in Genesis 6-9 is a version of an internationally evidenced narrative. (see Dundes 1988), but the biblical account of Noah shares an oiketype or more specific local version that circulated widely in the ancient Levant, featuring a hero named Atrahasis or Utnapishtim (Dalley 2008, pp. 1-38, 99-120). The Israelite version that is preserved in Genesis 6-9, no doubt is one telling among many in ancient Israelite cultures. If David Carr is correct, the composition in Genesis 6-9 may be an amalgamation of Israelite variants (Carr 2016b, pp. 108-9). This sort of comparative awareness allows the reader to appreciate not only universal human concerns and literary archetypes but also to assess the culture specific interests and worldviews of ancient biblical writers and their audiences.

The field of folklore also offers an alternate way of approaching structure and content, namely a morphological approach, associated with the Russian folklorist Vladimir Propp (1960). Propp's work became available in English in the mid-twentieth century and deeply influenced a seminal group of folklorists including Dan Ben-Amos (1966) and Alan Dundes (1965). Propp provided another source of interdisciplinary discourse shared by the fields of Bible study and folklore. In Propp's view, typological analysis can be too narrowly defined by specific content. More important is to understand the morphology of tales as defined by their "functions", their basic plot moves. The hero may be a lion or a man or a young girl, the conflict in the tale may involve a dragon or an evil step-mother, the 
opening problem of the tale may be economic distress or a threat from enemies, but if the essential plot steps are the same, then they share a structure, a morphology.

An important strength of Dundes and Ben-Amos' studies that are influenced by Propp's work is that they allow the narratives themselves to set the parameters of the morphology. Propp located his morphology in one hundred classic Russian tales or Märchen of the Afanyasev collection, but the stories of ancient Israelite traditions offer their own patterns as do the tales of native Americans studied by Dundes (1965) or the aggadic midrashim of the Rabbis explored by Dan Ben-Amos (1966). Jack Sasson's somewhat rigid application of Proppian morphology to the biblical book of Ruth is less successful than those of other biblical scholars who listen more closely to the biblical texts (Sasson 1979). Dorothy Irvin's morphological study of the pattern of the hero in the ancient Near East relies on the description of "plot moves", comparable to Propp's functions. Like Propp, she views the key events of these tales as critical to describing form (Irvin 1977). Robert Culley's study of action sequences in the Hebrew Bible (Culley 1976, 1990) and his student Pamela Milne's work with Daniel (Milne 1988) are also helpful morphological analyses that allow the reader to appreciate the working parts of the tales and the significance of variants that nevertheless adhere to the same basic form. So too Edward L. Greenstein's thoughtful study of the fugitive hero pattern (Greenstein 2015). Morphological interests also lie behind my effort to understand the stuff of biblical tales of underdogs and tricksters (Niditch 1987). The overlay map technique attempts to explore the content and structure of a set of biblical tales by tracing the tale in terms of a more general, generic model (i.e., problem/resolution) and more and more specific iterations of these key moves. Heda Jason (1984) has explored morphologies of the hero to see if male and female protagonists are differently presented, so that morphologies reflect the gender views of the narrator.

Dundes and other folklorists have attempted to delineate the morphology of other folk genres as well (Dundes 1975). His work with proverbs and riddles has figured prominently in biblicist Carole Fontaine's study of biblical wisdom genres (Fontaine 1982). She and Claudia Camp (Fontaine and Camp 1990), with whom she collaborated in an article on Samson's riddle, explored the morphology of biblical wisdom genres and then, influenced by Dundes, Kirshenblatt-Gimblett, and other folklorists, examined contexts for the deployment of these orally rooted forms and the meanings they convey as now situated and contextualized in biblical settings (see Dundes 1975; Kirshenblatt-Gimblett 1973; Mieder 2008).

Responding to Propp's morphological research, in fact, some scholars suggest that he paid too little attention to the worldview of authors and intended audiences and to the context of compositions. In Propp's own view, the definition of morphological structures was a necessary first step before one could approach such questions of context, meaning, and message. He realized, however, that these matters of meaning are extremely important (Propp 1984). Ways in which folklorists and biblical scholars do grapple with context, worldview, and culture as lived offer another important area of interdisciplinary engagement and possibility. The settings which frame the production and reception of folk genres, the cultures and daily realities that help to shape people's experience, and the orientations to life revealed by traditional genres and their reception are all critically important in the study of folklore and the Hebrew Bible.

In the field of religious studies, one increasingly sees interest in "religion as lived" and related notions of "material religion" and what is sometimes called "thing theory". Scholars of religion, and this is true as well of students of ancient Israelite religion, seek to understand the physical, sometimes embodied, non-verbal, tactile aspects of culture and the expression of individual and group identity, the sense of self in a shared tradition of being (Niditch 2015). As noted by Simon Bronner (2017) in a recent helpful overview, folklore as a scholarly field and as a cultural phenomenon is integrally related to the study of things and actions and people's involvement with them and reaction to them. Such concerns point to the way in which folklore is an interdiscipline that draws upon a variety of fields including anthropology and related ritual studies, sociology, fine arts, and psychology. For biblicists, the study of things and embodied action meets the material and non-verbal interests of folklore in the study 
of biblical descriptions of ritual behaviors (Bodel and Olyan 2008) and stylized prophetic activities (Wilson 1980), in descriptions of bodily adornment, clothing, and other bodily customs in Hebrew Bible and related ancient Near Eastern artistic evidence (Niditch 2008), and in archaeological evidence revealing of people's daily lives (King and Stager 2001; Stavrakopoulu 2016). The archaeological dimension as it relates to an understanding of culture, belief, and tradition is exemplified by the work of Avraham Faust (2016) who seeks to understand how objects unearthed by archaeologists relate to a group's sense of self, their ethnicity, the study of burial sites by Elizabeth Bloch-Smith (2004) who explores the group defining culture of interment, and the work of Theodore Lewis (2016) who explores the visual culture of the biblical world expressed in iconic imagery and objects.

Like students of contemporary religions and cultures, folklorists do ethnographic work, interviewing those who wear their hair in certain stylized ways, or who play certain games, or who engage in various culturally defining shared activities. They can ask interviewees about their assumptions, feelings, and identities, and can explore the significance and nature of their own involvement as scholar/participants. The strong emphasis on ethnography and discussions of the self-conscious role, responsibilities, and reactions of the participant observer figure prominently in essays published in the Journal of American Folklore (e.g., Yoshimura 2015; Sklar 2005; Roy and Frandy 2013; Prahlad 2005). Those of us who seek to understand ancient cultures and the people who lived them, working with detached archaeological evidence or written texts, face challenges. I would argue, however, that we can listen intelligently to the voices behind biblical and epigraphic texts and put together puzzles suggested by archaeological evidence, sensitive to patterns that emerge and allowing for the possibility of using live cultures as models (Niditch 2015, pp. 3-8).

Our own culture, of course, is deeply wedded to social media. Contemporary folklorists write about the immediacy of on-line interactions with real or imaginary beings, about the folkloristics of computer games, about the role of social media in the creation and sharing of various genres of folklore, and about the online communities created, matters explored, for example, in volume 128, Number 509 of the Journal of American Folklore. An area of deep interest to John Miles Foley before his death involved the connections or "homologies" as he put it between oral tradition and social media, communication via the Internet. Alan Dundes (1980b, pp. 17-19) anticipated this direction in folklore decades ago when computers took up a whole room. Foley's e-book (Foley 2012) Oral Tradition and the Internet (also available in a hard copy although he preferred that consumers of his work interact with the e-form) employs a new and to some unfamiliar vocabulary: epathways, owords, linkmaps, oAgora. Basically, he suggested "oral traditions amount to cultural intranets, complex, ever-ramifying networks of options that the performers effectively click into being" (Foley 2012, p. 224). He pointed to compositional spontaneity and the importance of improvisation in the creation of oral and oral-style literature. For him both oral tradition and the Internet involve participation in pathways within networks. We recall here Ben Amos' emphasis on folklore as a communicative process. Foley insisted that "pathways matter, not things" a theme emphasized recently also by Simon Bronner (2017, pp. 21-25). This thread in folklore is also represented in contemporary biblical studies, for example in Jeffrey Siker's study of the use of digital Bibles so that the text becomes thoroughly interactive, a "liquid Bible" (Siker 2017).

Another modern arena where the study of the Hebrew Bible meets the interests of folklore is the annual section of the Society of Biblical Literature in Biblical Performance Criticism. "Biblical performance criticism" is a phrase based on "form-criticism", "redaction-criticism", "source criticism" and other methodologically significant means of approaching the Bible. Biblical performance criticism offers ways of exploring the Hebrew Bible, its world, and its reception alert to folklorists' emphasis on process, oral tradition, context, audience, media, and cultural communication. The interests of this group are wide-ranging including attention to the actual performance of Scripture, questions concerning oral transmission in ancient communities and the border where traditional-style written media meet works composed and performed orally. Scholars explore the Bible in ancient and modern media dealing not only with Hebrew Bible itself but also with the presence of Bible in 
electronic media. At the 2017 meeting of this group, scholars in a panel on Israelite prophetic literature were invited to approach "prophetic media as aesthetic artifacts". Another panel concentrated on "iconic and performative texts", with interest in the "social functions of books as cultural artifacts, their ritual use, their performance by recitation and theater, and their depiction in art". Interests thus include the qualities and contexts of ancient works, the possible performance dynamics of these works, the re-oralization and re-contextualization of Scripture in various media, the material culture of ancient Israel, and the subsequent use of related artifacts, including Bibles themselves.

Related to the on-going work of the Biblical Performance Section of the Society of Biblical Literature is a new reference work, The Dictionary of the Bible and Ancient Media (Thatcher et al. 2017). This volume produced by biblical scholars and aimed at their colleagues makes available brief introductory articles on many aspects of scholarship in folklore, oral studies, and related inter-disciplines. An informative and educative work, the dictionary both reflects an increased awareness among some biblical scholars about the relevance of folklore to the study of the Hebrew Bible and is an effort to make available to students of ancient Israel a means of introducing themselves to key terms, names, and subjects that are within the purview of folklore studies.

And yet, despite these ongoing interests it would be less than accurate to suggest that folklore is highly influential in biblical studies nowadays or as significant as one might have predicted from creative scholarship of the twentieth century or from the more recent work described above. Important trends seem to suggest that work in oral-traditional literature and folklore studies currently has little influence on the study of Hebrew Bible in some quarters or that the influence of folklore even if implicit is not fully recognized or appreciated. I want to offer two case studies, the work of Joel S. Baden and that of Andrew Teeter, erudite thoughtful scholars but ones for whom Gunkel's interest in texture and life-setting, so related to the study of folklore, then and now, is undervalued.

\section{3. "Bible without Folklore" in Current Scholarship}

To understand the orientations of Joel S. Baden $(2012,2016)$ and his intellectual confreres one needs to look back not to Gunkel but to Julius Wellhausen, the best known of the biblical source critics. Building on the work of a host of European predecessors, Wellhausen (Wellhausen 1965) looked at language, especially names for the deity, orientation, and seeming doublets and lacunae in the Pentateuch to postulate that four major biblical written documents lie behind this corpus as it now stands: P, the Priestly work; J, the work of the Yawhist; E, the work of the Elohist; and D the work of the Deuteronomist. For our purposes in exploring the interaction between the Hebrew Bible and folklore, there is no need to go more deeply into debates about the precise dates and content attributed to these sources. It does need to be said, however, that the entire enterprise seems at odds with factors to which folklorists are sensitive: the existence and appreciation of variants in any tradition and especially the concern with the contexts and the material logistics of writing, copying, and combining set texts. To be sure, the Bible is a rich tapestry reflecting various contributors and periods. The interplay between oral and written, texts set in manuscript and in memory, is complex. The documentary hypothesis, however, tends to ignore questions about the logistics of writing in the ancient world of Israel in which there were no folios or codices but scrolls, and in which only the scribal elite had access to such scrolls. Even allowing for such access, the creation of new documents by the cut and paste process Wellhausen imagined seems at odds with what is known about the logistics of writing and copying manuscripts in the ancient Levant (Niditch 1996, pp. 60-77). Contemporary scholars such as David Carr $(2005,2016 a, 2016 b)$ have attempted to reimagine the "documentary process", combining what we know about oral tradition, scribal convention in the ancient Levant, the role of memory, and the ways in which ancient copyists and redactors are also composers. These composers evidence oral-traditional sensibilities and share a tradition with those who compose more extemporaneously in performance.

David Carr approaches questions about redaction and compilation in humanistic terms asking about how and why the material was gathered together in the form we now have, allowing for the 
voices of the creators, processes of memorization and performance, an oral-written continuum and a prehistory in oral tradition (Carr 2016b, p. 104; Carr 2005), all ways in which "folklore matters", to borrow the title of one of Alan Dundes' books (Dundes 1989). For Joel S. Baden, however, it is as if none of these issues have significance.

Baden sees the Pentateuch as composed of four independent written documents that were combined and interwoven by a compiler. He does not address issues relating to oral transmission. He insists we can know nothing about this compiler in terms of worldview and dating the documents is not for him a central concern (Baden 2012, p. 32). What of worldview or socio-historical context? Wellhausen tried to understand the world and concerns that are reflected in J, E, P, and D. Baden writes, however, "The theological intentionality is not to be found in the text of the compiled Pentateuch, but rather in the very act of compilation itself" (Baden 2012, p. 228).

Ironically, Baden himself critiques some source critics who suggest that the sources behind the opening books of the Bible are in places virtually unreadable as continuous narration because of the supposed gaps e.g., the lack of adequate information about Moses' birth and origins in the J narrative as Baden and others delineate it (Baden 2016, pp. 283-84). He suggests on the contrary that "continuity is a sliding scale", a somewhat subjective category (Baden 2016, p. 292). He notes that despite narrative gaps in the Ugaritic Kirta narrative, we can still speak of a Kirta epic (Baden 2016, p. 289). We might add that while picking apart the tale of Noah has been a favorite preoccupation of source critics, centuries of readers and receivers have been comfortable with the biblical telling, not deterred by supposed examples of Homer's nodding. The variations, additions, and alterations contributed by scribes have become a part of the tradition, their role not merely that of copiers but of composers. This is to appreciate the use of writing in an essentially oral world (Person and Rezetko 2016, pp. 20, 29).

Andrew Teeter's recent article "Methodological Reflections" on Second Temple literature (Teeter 2013) and contributions to the symposium on "Wisdom and Torah" in the Second Temple period organized by him and Bernd Schipper (Schipper and Teeter 2013) shed light on another influential new direction in the study of the literature of the Hebrew Bible, one that has direct bearing on questions concerning folklore and the Hebrew Bible. First, we list a number of the ways in which Teeter's essay in particular comports with some of the suggestions made above concerning the relevance of folklore studies and the related field of early and oral literatures to the study of the Hebrew Bible.

Teeter notes that the search for an Ur-texts that so characterized certain earlier threads in biblical studies is fruitless (Teeter 2013, p. 373). The tradition is always being received, renewed, and renovated, in a state of flux. The folklorist would say that multiplicity or variation is a key trait of this sort of traditional literature. He suggests that the Hebrew Bible is ultimately Second Temple literature, for these are the writers who get the last word (Teeter 2013, p. 351). He points out that our concept of the "life settings" of literary genres needs to be much more variegated and complex than some older studies allowed, for works characterized by a shared sort of form and content might find multiple purposes or settings (Teeter 2013, p. 365) We must reject the notion, for example, that liturgy was the environment for compositions of a certain kind. A particular saying form may well characterize a certain cultural genre, but a folklorist would remind us that this same form, even this very same saying, might find differing contexts and be employed under different circumstances with variations in tone, audience, gesture, and message. Teeter also asks about the ways in which exegesis relates to composition. Implicitly he raises a question of interest to folklorists about the artistic or compositional process when everyone already knows the story. None of these points is entirely new, but the framework and the assumptions are innovative, for Teeter suggests that "the internal development of the Hebrew Bible is, in a specific and important sense, a history of exegesis", (Teeter 2013, p. 350), drawing comparisons with compositions produced by Qumran covenanters and other Second Temple writers. For Teeter, moreover, there is no engagement with questions of material culture or context. This is a weakness in his work and a way in which his assumptions greatly differ from those of folklorists. It is all well and good to see the Sitz-im-leben imagined by Mowinckel or Gunkel as problematical, but there is always some social and historical context. Actual humans being set in time, place, and culture produced 
these works. They did not emerge superorganically. Indeed, such address to superorganic processes was a great weakness of some 20th century folklore that imagined folktales developing and changing without address to how or by whom, or exhibiting certain structures and recurring content without attention to sociological or psychological dynamics, issues of communication and transmission.

For Teeter texts seem to talk to texts. He writes "Describing exegetical function is a matter of ascertaining how a text as a communicative act was designed to function in relation to another writing, with exegesis (as explanation) being only one form of engagement among many" (Teeter 2013, p. 366). He alludes to a "communicative practice" but who is communicating with whom? How does communication happen? What are the setting and purpose of any communicative act? These questions are at the heart of folklore. What, moreover, are the logistics by which texts are copied, edited, and altered? Is he imagining work from scroll to scroll or the intermediary use of tablets or codices or are texts memorized in fixed form?

To his credit, he speaks to the "traditionary character of the Hebrew Bible" but also seems to jettison the tradition itself. The "implied readership" of the Hebrew Bible requires "a robust and highly sophisticated literary competence" (Teeter 2013, p. 356). Elites write for elites and again texts always relate to texts "in relation to another writing" (Teeter 2013, p. 366). The exegetically aware orientation is all well and good, but would he deny the existence of oral traditions that influence the written and vice versa in a creative tradition-forming process? Composition for him is all about exegesis. "The tradents (scribes/authors/redactors) responsible were involved in a massive exegetical process of synthesis, coordination, and amalgamation" (Teeter 2013, p. 358). Is their goal at least in some cases at various points in the growth of the biblical and related tradition not to produce story rich in meaning and message, to produce an aesthetically pleasing, audience-oriented work? Why then have the works of Hebrew Bible managed to function on those levels for generations of subsequent receivers? One might suggest that Teeter, like Carr and Schniedewind, is interested in the process by which the Bible becomes a book, perhaps many books, and yet his own work indicates how open that "book" is to a continuing process of composition, development, and reception, as the rich Rabbinic corpus indicates.

Teeter does view exegesis as a broad term (Teeter 2013, p. 363), and allows that interpretations of written texts may be "subordinate to larger rhetorical or literary goals" (Teeter 2013, p. 363). He notes that "textual engagement and reuse is a dynamic and polymorphous phenomenon that often must be grasped intuitively and addressed on multiple levels simultaneously" (Teeter 2013, pp. 363-64). The sources of versions and variants, however, even if exegetical and intertextual in the broadest and most flexible ways, for him still involve manuscripts rather than participation in and reception of a shared tradition in a process of recreation that Foley calls "imminent art", a process that need not rely only upon manuscripts but on a wider range of cultural referents.

He uses the term "canon" suggesting "the reality of a certain pre-canonical "canon-consciousness" (Teeter 2013, p. 376) that leads the writers now represented in biblical and related post-biblical texts to approach literature in the ways he imagines, resulting in these related texts. However, what canon has multiple equally valued versions of a prophetic corpus as is the case with versions of Jeremiah found at Qumran, shorter and longer versions of 1-2 Samuel, and so on? Multiplicity, variation, versions are at the heart of traditions, written and oral.

Ultimately little has changed in the old paradigm, rooted in the notion of sources and a world of writing elites and indeed Wellhausen is back with a roar but without his sensitivity to socio-historical contexts. Baden and Teeter lack interest in trying to describe the social contexts that produced manuscripts. They express doubts about the form-critical enterprise, and they like many contemporary Bible scholars, treat the Bible as a late Second Temple scribal work. They devote inadequate attention to the lengthy cultural tradition that reflects and affects a much wider folk group. Questions about the coming together of the Bible as it now stands are important. Some of these questions may not, in fact, be fully answerable as noted by a number of the scholars who contribute to a recent volume that examines "empirical models challenging biblical criticism" (Person and Rezetko 2016). If, however, 
scholars fail to take seriously the oral-traditional qualities of these ancient texts and implications of that aesthetic for appreciating the cultural environments in which composers lived, their work is the poorer. The application of ideas and approaches found in the field of folklore can assist biblical scholars to a transcend a failure of imagination, and to resist a somehow irresistible desire to picture the ancients being just like them, scholars poring over texts.

\section{Case Studies}

The final portion of this reflection on the Hebrew Bible and folklore offers a series of case studies that underscore how important this interdisciplinary work is to a full appreciation of the literature of Hebrew Bible: an examination of a biblical proverb employed by Jeremiah and Ezekiel; a brief comparative study of tales of wise courtiers in Genesis 41 and Daniel 2; an assessment of a formula pattern concerning the warrior in Judges 5; and comments on the story of Eden in Genesis 2-3.

\subsection{Māsāal in a Prophetic Context}

A first case study is provided by a māššl (an Israelite ethnic genre rooted in the meaning "to be like") addressed to Israelites by the 6th century BCE prophets Ezekiel and Jeremiah, "Parents eat (have eaten) sour grapes, and the teeth of the children twinge". Biblical scholars typically explore the saying theologically. Michael Fishbane interprets the prophets' message to be, "those in exile are there for their own sins and not those of their parents, and since their relationship with God is not an intractable or inherited fate they can take responsibility for it and return to YAHWEH" (Fishbane 1984, pp. 141-42). Paul M. Joyce suggests, "The prophet addresses an audience who are blaming previous generations for the disaster of exile... He rejects this saying and with it his audience's denial of responsibility for their fate" (Joyce 1989, p. 35). Similarly, Barnabas Lindars notes, "The people hide behind the old conception of an extended retribution ... in order to avoid their own responsibility for their plight" (Lindars 1965, p. 462). However, if one draws upon comparative material and allows for the varied situations in which such a proverb might take on meaning, apart from a strictly theological orientation, other possibilities present themselves.

Were we situated in an actual ancient Israelite culture, we could engage in the kind of ethnograpahic work practiced by folklorists Alan Dundes (1979) and Barbara Kirshenblatt-Gimblett (1973), observing the various ways in which the sour grapes saying is employed or asking people to imagine such a setting and describe it. We could listen to the inflection of the speaker and assess the relative status of the speaker of the proverb and those to whom it is addressed. Kirshenblatt-Gimblett (1973) and Dundes (1979) both have found that proverbs have various connotations even within the same folk group. The meaning conveyed depends upon the specific context and situation that gives rise to proverb performance, the relationship between the speaker and those who are addressed, the tone of the speaker, the version of the proverb to which they have been previously exposed, and other factors. The prophet may attach one meaning to this proverb in the imagined or constructed performance scene whereas people generally understand the saying in another way. Why is this proverb cited in these exilic period texts and can we tell from the written contexts what range of meanings may have been associated with it?

Dundes wrote, "Folklore provides a socially sanctioned framework for the expression of critical anxiety-producing problems as well as a cherished artistic vehicle for communicating ethos and worldview" (Dundes 1980b, p. 9). He suggested that forms of communication such as the proverb with their culturally recognizable structures and flexible, wide-ranging applicabilities, help people to grapple with challenges, "the twinging" that human beings, set in culture, experience during their lifetimes and that become especially acute in periods of crisis, communal or individual. The period of Babylonian conquest, as with any situation of war, with its deaths, deprivation, and forced migrations, induced inner turmoil and conflict. Scholarly approaches to this particular proverb are generally less attuned to such considerations of context and function that interest folklorists than to matters 
of theology, and consistently interpret its meaning monolithically in terms of disobedience to God and punishment.

The proverb addresses central and troubling ambiguities that define being human and offers one way to cope with anomie, the senselessness of suffering, the sources of disruption and dislocation. As social anthropologist Clifford Geertz has written, "The effort is not to deny the undeniable- that there are unexplained events, that life hurts, or that rain falls on the just-but to deny that there are inexplicable events, that life is unendurable, and that justice is a mirage" (Geertz 1978, p. 108). In the Judean community, there must have been people who remembered Isaiah's promises about the inviolability of Jerusalem and divine protection for Yahweh's people (Isa 29:5-8; 31:4-9; 37:33-35). There must have been those who lost their families, innocent children who were injured or killed. There must have been people who believed themselves to be decent folks whose lives were utterly upturned. If they could say that the misdeeds of previous actors caused current suffering, they somehow might explain the trauma and accept it.

The proverb quoted by Ezekiel and Jeremiah thus offers a piece of conventional wisdom that comforts, not as many scholars suggest because it deflects the people's own responsibility for sin, but because it offers some reason for suffering. It is one of many such explanations that make suffering interpretable. Here we return to questions about context and performance, imagined speakers, and their audiences.

The prophets and the people approach the proverb from different perspectives. The prophets are concerned with God's fairness. Undeserved suffering is simply not fair. The people however, see the proverb as a means to make unfairness comprehensible. The world may be unfair, but it is not, to reprise Geertz's essay, utterly mad. Attribution of the suffering to events and generations of the past helps one cope, even if the suffering does not seem fair. Suffering is at least explicable. Like the healing rituals explored by Geertz, the proverb about sour grapes has "the ability to give the stricken person a vocabulary in terms of which to grasp the nature of his distress and relate it to the wider world" (Geertz 1978, p. 105). The prophets, however, wrestling with questions of theodicy, are disturbed to think that the one God may be punishing innocent victims. For the people suffering is an unexplained problem, whereas for the prophets it is a moral dilemma.

The true richness of these scenes of proverb performance and the complex tensions that characterize the relationship between the prophets and those they are imagined to address are revealed by folklore inspired study. Awareness of the malleability of proverb meaning, attention to the importance of context, and alertness to psycho-social functions of this folk genre allow the reader to move beyond pat theological interpretations to gain a better sense of ancient Israelite culture as lived.

\subsection{Tales of Wise Courtiers in Genesis 41 and Daniel 2}

Genesis 41 and Daniel 2 are tales about wise courtiers whose capacity to interpret dreams saves their lives and the lives of those around them. The tales share not only a pattern of events but also specific language by which content is expressed. The pattern expressed in general terms is that a person of lower status is called upon to solve a difficult seeming irresolvable problem for a person of higher status; the person of lower status does solve the problem; reward and increase of status follow. This pattern characterizes Thompson Type 922, an international tale type about the success of the wise person. The biblical tales of Joseph and Daniel specify these motifs in a very similar way: for example, the low status of each hero is because he is an exile, the person of high status is the leader of the country to which the hero has been exiled, the difficult problem is to interpret the leader's troubling dream. The effort of the king to find someone to solve his problem is described in formulaic language that employs the verb "to call" + a selection of terms for wise men and advisors, e.g., magicians, wise men, courtiers (Gen 41:8; Dan 2:2; see also Exod 7:11). Similarly, a shared formula pattern describes the bestowing of the award: verbal element of appointing + object + prepositional link connoting authority over + term for royal provenance (Gen 41:33; 41:41; Dan 2:48). This commonality in plot, 
content, and language has generally led biblical scholars to posit dependence of the Daniel text on the story of Joseph in Genesis 41. The implication, in line with the methodological tendenz of biblical scholarship discussed earlier, is that the author of Daniel had before him or in his mind the set text of Genesis and that he borrows, or alludes to, or quotes from this earlier text in a process of "interliterary allusion". (Lester 2015, p. 47) Some suggest, in fact, that Daniel 2 is a midrash or exegesis on the story of Joseph found in Genesis (Lester 2015, pp. 54-44, n. 130).

This older-style approach to intertextuality common among biblicists emphasizes re-use of or commentary upon a specific source rather than the availability of a shared tradition reflected in oral and written material, a way of speaking and writing, of expressing content that John Miles Foley (1991) called "traditional referentiality". It is important to note for example that the formula about calling to wise men is also found concerning Pharaoh in Exod 7:11 and in the tale of the court wise-man, Ahiqar, a work of antiquity, preserved in several translation traditions. This language is a metonymic or shorthand indicator that the tale deals with a court contest, matters of status, and the soon to be revealed wisdom of the underdog hero. In ignoring the wider significance and use of the formula pattern, scholars fail to appreciate fully the recurring language characteristic of traditional literature, often written works produced in a cultural milieu influenced or contoured by oral-traditional aesthetics and expectations. Inadequate attention to the tales' recurring content similarly does not allow them to take account of the humanistic dimensions of narratives such as Genesis 41 and Daniel 2, Israelite versions of type 922, e.g., concerns with status, the tendency to root for the little guy, people's fascination with puzzlers and mysteries, or to engage in the comparative work that underscores what is culturally special and defining about the biblical usage of a familiar cross-culturally evidenced narrative pattern. If one moves from the more generic pattern suggested by all the tales that belong to Thompson's type to specific Israelite versions, the special concerns and orientations of the latter emerge.

One message is that Yahweh is the sender and solver of all difficulties. The use of the dream as the problem to solve in these versions of type 922 portrays dreams as divinatory media that may be interpreted to understand their relevance and meaning. Indeed various ancient Mediterranean societies produced collections of dream omina and sophisticated professionals skilled at the interpretation of dreams. The specification of the "difficult question" as a dream to be interpreted points in this valuable, culturally important direction. The implication of Daniel 2 and Genesis 41 is that God may communicate via dreams and that he enables interpreters such as Daniel and Joseph. It is important, moreover, that the person of high status comes to recognize the power of Yahweh and declares his praise, a favorite theme of the ancient Israelite national anthology. In this way, we gain added insight into the culture that backgrounds these versions of type 922 and to the religious orientations of their authors.

\subsection{A Catalogue of Warriors in Judges 5}

Language at the center of the victory song in Judges 5 provides a third case study in folklore and the Hebrew Bible by challenging the historicism that sometimes characterizes the treatment of ancient Israelite literature. An early biblical work, perhaps dating to the 12th century BCE, composed in the parallelistic style of ancient Near eastern poetry, the Song of Deborah describes Israel's defeat of Canaanite kings. The song employs traditional motifs such as "the iron fist in the velvet glove" (Judg 5:24-27) and includes deeply mythological portrayals of the role of Yahweh the divine warrior, whose cosmic forces combine with the bravery of Israelite warriors to achieve victory. As in Iliad 3:160-244, a catalog of warriors describes the participant groups in the battle beginning at Jud 5:14-15, with the mention of Ephraim, Benjamin, Machir, Zebulun, and Issachar, all of whom are said to join the leaders Deborah and Barak. At the end of v.15-v.16 small text-critical and translation choices arise, and depending upon how one treats a verb concerning Reuben in vv. 15-16 and understands one word, different messages emerge.

There seems to be some confusion in the textual tradition as to whether one should read a verb $h q q$ (as in MT 5:15) that suggests a nuance of resolve or $h q r$ that has the nuance of self-doubt 
(as in MT 5:16). Is Reuven resolved and stout-hearted or unsure and self-searching? A second problem involves the word $l m h$. This word is usually translated "why", its typical meaning in biblical Hebrew. Basing his translation on a linguistic parallel in the Northwest Semitic language, Ugaritic, Frank Moore Cross (1973) suggested that $l m h$ in Judges 5 might better be translated "verily" (Cross 1973, p. 235, n. 74; Cross 1998, pp. 54-55). Judg 5:16-18 thus may be a continuation of the catalog with formulas referencing content including some or all of the following: the name of the group, where they dwell, what their occupations are, and how brave they are.

The more usual translation, reflected in the NRSV, is as follows. It reads the "doubt" verb hqr in Judg 5:15 and 5:16 instead of $h q q$ meaning resolve, employs the typical "why" translation of $l m h$, and reads certain common verbs such as "to dwell" or "reside" to suggest hesitation and holding back.

Among the clans of Reuben

There were great searchings of heart

Gilead stayed beyond the Jordan

And Dan why did he abide with the ships?

Asher sat still at the coast of the sea

settling down by his landings.

According to this translation and reading, the composer is seen to ask essentially, why did these groups refrain from fighting? However, allowing for a quite literal reading of the verbs, Cross' suggestion for $l m h$, and the "resolve" verb we have as follows.

In the divisions of Reuben,

great are the stout-of-heart.

Gilead in the Transjordan plies his tent,

and Dan, verily he resides in ships.

Asher dwells on the shore of the sea

and on its promontories, he plies his tent.

The latter translation allows for the more typical and ordinary meaning of the verbs, but also suits the context of the larger song, for 5:17 continues with praise for other participants in the battle, Zebulun and Naphtali, whose geographical locus is also cited, as in the case of Gilead, Dan, and Asher. A formula pattern is at work, one found also in Gen 49:13, 16:12, and Deut 33:18-19, (tribe + location + tenting/residing). The song does include a critique of those who did not participate but not until a later portion of the song in 5:23. Therefore, the logic of the work, the more literal reading of verbs, and the presence of a traditional form such as the catalog of warriors recommend the latter reading.

The approach of Bible scholar and archaeologist Lawrence Stager differs. Stager accepts the more usual translation of Judg 5:16-17 and does not find it jarring perhaps precisely because he feels he can match the implications of the song as often translated with the actual geographic, historical, and economic situations of these groups in the early Iron Age (1200-1000 BCE). Stager finds a reason for the reticence of Reuben, Gilead (Gad), Asher, and Dan to participate in the battle and sees these verses as reflecting a kind historical "verisimilitude" or plausibility, even if the precise events never happened (Stager 1989, p. 55). He argues that the tribes of Reuben and Gilead (Gad) occupied a pastoralist niche in the economy, a line of work that made it difficult to drop everything and go fight. Dan and Asher, as sea-faring tribes, were economically involved with the activities of Canaanite estates and maritime activities and reticent to join the Israelites in wars against those with whom they had economic ties. Stager's argument is indeed erudite but is not attentive enough to the thematic cohesiveness of the song or the implications of formulaic language.

\subsection{Reading Eden}

A final case study that supports the importance of folkloristic sensibilities in the study of the Hebrew Bible is provided by the iconic story of Eden. From Augustine to Milton to C. S. Lewis 
to a host of modern biblical scholars, the tale about the first man, first woman, and the snake in Genesis 2-3 is treated as cautionary tale about "sin and shame", "the Fall" (Von Rad 1961, p. 88; Westermann 1984-1986, vol. 1, p. 277). The story about eating from the tree of knowledge in defiance of a divine prohibition plays a similar role in popular imagination and is shaped largely by theological orientations derived from threads in classical Christian worldview. If, however, one approaches the tale of Eden with the comparative interests of a folklorist, a different interpretation of and deeper appreciation for the story's meaning and messages emerge. The morphological approach proposed by Propp $(1960)$ and the typological approach of Thompson $(1955-1958,1973)$ are both useful analytical tools in exploring the tale of the Garden of Eden.

Morphologically the tale is comprised of four key motifs: an ideal and idyllic situation; a prohibition, either explicit or implicit, (in this case, not to eat from the tree); the breaking of the prohibition (eating the fruit); the onset of reality with its difficulties, social structures, and death. In fact, this morphology not only categorizes the tale of Eden but two more tales in Genesis 1-11, the so-called "primeval history of the Bible", the story of the descent of God's sons in Gen 6:1-4, and the story of the tower of Babel in Gen 11:1-9. In Gen 6:1-4 an apparently unlimited life-span is limited after the sons of God mate with the daughters of men, breaching another kind of divine territoriality. In the tower story, the ideal is a world with one language, and the apparent forbidden breach of territoriality / affront to God is neither alimentary nor sexual, but spatial, attempting to build a tower to the heavens. The consequence is a world divided by language, a salient manifestation of cultural reality with its social divisions and categories. Awareness of a morphological or generic pattern that can be filled in in various specific ways by different story-tellers alerts us to shared concerns in Israelite culture and to the creative ways in which individual authors can adapt the story to grapple with these concerns. Clearly, the ancient Israelite authors believe there is a demarcation between divine and human, heavenly and earthly and that attempting to blur this boundary is dangerous. At the same time, the authors of the stories in Genesis employ quite universal imagery of mediation or boundary-blurring: sharing food; having sex; speaking a common language.

It is important to emphasize that the word "sin" is not used in Genesis 2-3. The frequent attribution of humans' sinfulness to the first foundation story is to over-theologize it and to miss out on a universal human concern with explanations for the challenges of reality. The use of Thompson's catalogs of motifs and types provides a cross-cultural range of stories that allow us to see the tale of Eden in a wider humanistic context.

In contrast to the description of motifs or functions in the morphological approach, Thompson's types and motifs are very content specific. That is, one cannot check the Indices under "reality" and expect to find comparable tales, but is far more successful searching under "death", one of the concrete aspects of post-Eden life that is emphasized in the Genesis account. Motifs A1330 ("Beginnings of trouble for man")-A1335 ("Origins of death") offer a large international set of narratives comparable to Genesis 2-3 in which death enters the world due to the "breaking of a taboo" to use Thompson's terminology and often because of the machinations of a trickster figure such as the serpent. This trove of cross-culturally evidenced material allows us to explore both the universality of certain concerns and the uniqueness of the Eden tale. The details of reality after eating from God's tree not only emphasize that death is inevitable for human beings in contrast to the immortality of God and his retinue but also underscore the hierarchy between men and women in which men hold the power and the author's strongly agricultural interests, for farming is a difficult often unyielding way to make one's living. The tale seen comparatively also emphasizes more universally the human desire to explain why the world is as it is, with hard work, social structures, gender differences, and, ultimately, death. Each of these tales contain a wistful imagining of a better, calmer, more idyllic life and offers a reason for its loss, one out of the control of people who hear the story. All these formative "events" happened way back in mythic time, and so reality must be accepted as it is. These are important universal concerns and messages that transcend culture and period, and awareness of them liberates the reader from 
heavily theological readings of Genesis 2-3, allowing one to read the biblical account in the rich context of traditional literatures, world-wide.

\section{Summation}

We have reviewed the fruitful interactions between fields of folklore and biblical study from the early 20th century until the present, making the case for the continued relevance of folklore studies to an appreciation of the literature and culture of ancient Israel. We have explored new trends in folklore and biblical studies. Finally, we have provided case studies that point to the richness of interpretive results when the scholar is immersed in interdisciplinary work, allowing for cross-cultural comparison and deeply humanistic inquiry.

Conflicts of Interest: The author declares no conflict of interest.

\section{References}

Alter, Robert. 1981. The Art of Biblical Narrative. New York: Basic.

Alter, Robert. 1990. Samson without Folklore. In Text and Tradition: The Hebrew Bible and Folklore. Semeia Studies; Edited by Susan Niditch. Atlanta: Scholars Press, pp. 47-56.

Baden, Joel S. 2012. The Composition of the Pentateuch. Renewing the Documentary Hypothesis. New Haven: Yale University Press.

Baden, Joel S. 2016. Continuitybetween the Gaps-The Pentateuch and the Kirta Epic. In The Formation of the Pentateuch. Bridging the Academic Cultures of Europe, Israel, and North America. Edited by Jan C. Gertz, Bernard M. Levinson, Dalit Rom-Shiloni and Konrad Schmid. Tübingen: Mohr Siebeck, pp. 283-94.

Ben-Amos, Dan. 1966. Narrative Forms in the Haggadah: Structural Analysis. Ph.D. dissertation, Indiana University Press, Bloomington, IN, USA.

Ben-Amos, Dan. 1972. Toward a Definition of Folklore in Context. In Toward New Perspectives in Folklore. Edited by Américo Paredes and Richard Bauman. Austin: University of Texas Press, pp. 4-15.

Ben-Amos, Dan. 1976. Analytical Categories and Ethnic Genres. In Folklore Genres. Publication of the American Folklore Society; Bibliographical and Special Series 26; Austin: University of Texas.

Bloch-Smith, Elizabeth. 2004. Resurrecting the Iron I Dead. Israel Exploration Journal 54: 77-91.

Bodel, John, and Saul M. Olyan, eds. 2008. Household and Family Religion in Antiquity. Oxford: Blackwell.

Bronner, Simon J. 2017. Folklore. The Basics. New York: Routledge.

Carr, David M. 2005. Writing on the Tablet of the Heart. Origins of Scripture and Literature. Oxford: Oxford University Press.

Carr, David M. 2016a. Data to Inform. In The Formation of the Pentateuch. Bridging the Academic Cultures of Europe, Israel, and North America. Edited by Jan C. Gertz, Bernard M. Levinson, Dalit Rom-Shiloni and Konrad Schmid. Tübingen: Mohr Siebeck, pp. 87-106.

Carr, David M. 2016b. The Formation of the Hebrew Bible: Sources, Compositional Layers, and Other Revisions. In The Wiley Blackwell Companion to Ancient Israel. Edited by Susan Niditch. Chichester: Wiley Blackwell, pp. 103-17.

Cross, Frank Moore. 1973. Canaanite Myth and Hebrew Epic. Cambridge: Harvard University Press.

Cross, Frank Moore. 1998. From Epic to Canon. History and Literature in Ancient Israel. Baltimore: Johns Hopkins Press.

Culley, Robert C. 1967. Oral Formulaic Language in the Biblical Psalms. Near and Middle East Series 4. Toronto: Univesity of Toronto Press.

Culley, Robert C. 1976. Studies in the Structure of Hebrew Narrative. Semeia Supp. 3; Missoula: Scholars Press.

Culley, Robert C. 1986. Oral Tradition and Biblical Studies. Oral Tradition 1: 30-65.

Culley, Robert C. 1990. Five Tales of Punishment in the Book of Numbers. In Text and Tradition. Edited by Susan Niditch. Atlanta: Scholars Press, pp. 25-34.

Dalley, Stephanie. 2008. Myths from Mesopotamia. Creation, the Flood, Gilgamesh, and Others. Oxford: Oxford University Press. Doane, A. N. 1994. The Ethnology of Scribal Writing and Angle-Saxon Poetry: Scribe as Performer. Oral Tradition 9: 420-39.

Dundes, Alan. 1965. The Morphology of North American Indian Tales. FFC 195; Helsinki: Suomalainen Tiedeakatemia. Dundes, Alan. 1975. On the Structure of the Proverb. Proverbium 25: 961-73. 
Dundes, Alan. 1979. Proverbs and the Ethnography of Speaking Folklore. In Analytic Essays in Folklore. Studies in Folklore 2. The Hague: Mouton, pp. 35-49.

Dundes, Alan. 1980a. Texture, Text and Context. In Interpreting Folklore. Bloomington: Indiana University Press, pp. 20-31.

Dundes, Alan. 1980b. Who are the Folk? In Interpreting Folklore. Bloomington: Indiana University Press, pp. 1-19. Dundes, Alan, ed. 1988. The Flood Myth. Berkeley and Los Angeles: UC Press.

Dundes, Alan. 1989. Folklore Matters. Knoxville: University of Tennessee Press.

Faust, Avraham. 2016. The Emergence of Israel and Theories of Ethnogenesis. In The Wiley Blackwell Companion to Ancient Israel. Edited by Susan Niditch. Chichester: Wiley Blackwell, pp. 155-73.

Fishbane, Michael. 1984. Sin and Judgment in the Prophecies of Ezekiel. Interpretation 38: 131-51. [CrossRef]

Foley, John Miles. 1991. Immanent Art: From Structure to Meaning in Traditional Oral Epic. Bloomington: Indiana University Press.

Foley, John Miles. 2012. Oral Tradition and the Internet. Pathways of the Mind. Urbana: University of Illinois Press.

Fontaine, Carole R. 1982. Traditional Sayings in the Old Testament. A Contextual Study. The Bible and Literature 5. Sheffield: Almond Press.

Fontaine, Carole R., and Claudia V. Camp. 1990. The Words of the Wise and their Riddles. In Text and Tradition. The Hebrew Bible and Folklore. Edited by Susan Niditch. Atlanta: Scholars Press, pp. 127-51.

Fox, Everett. 1995. The Five Books of Moses: Genesis, Exodus, Leviticus, Numbers, Deuteronomy. A New Translation with Introductions, Commentary, and Notes. New York: Schocken.

Frazer, James George. 1911-1915. The Golden Bough, 3rd ed. 12 vols. London: Macmillan.

Gaster, Theodore H. 1981. Myth, Legend, and Custom in the Old Testament. A comparative study with chapters from Sir James George Frazer's Folklore in the Old Testament; 2 vols. Gloucester: Peter Smith.

Geertz, Clifford. 1978. Religion as a Cultural System. In The Interpretation of Cultures. New York: Basic Books, pp. 87-125.

Greenstein, Edward L. 2015. The Fugitive Hero Narrative Pattern in Mesopotamia. In Worship, Women, and War. Essays in Honor of Susan Niditch. Brown Judaic Studies 357; Providence: Brown University, pp. 17-35.

Gunkel, Hermann. 1987. The Folktale in the Old Testament. Translated by Michael D. Rutter with an introduction by John W. Robertson; Sheffield: Sheffield Academic Press, Originally published as 1917. Das Märchen im Alten Testament; Tübingen: J.B.C. Mohr.

Gunkel, Hermann. 1926. Die Psalmen Übersetzt und Erklärt, Göttingener Handkommentar zum Alten Testament, II/2. 4th ed. Göttingen: Vandenhoeck \& Ruprecht.

Gunkel, Hermann. 1966. The Legends of Genesis. New York: Schocken.

Gunn, David. 1974. Narrative Patterns and Oral Tradition in Judges and Samuel. Vetus Testamentum 24: $286-317$. [CrossRef]

Hasan-Rokem, Galit. 1990. And God Created the Proverb ... Inter-Generic and Intertextual Aspects of Biblical Paremiology - or the Longest Way to the Shortest Text. In Text and Tradition. The Hebrew Bible and Folklore. Edited by Susan Niditch. Atlanta: Scholars Press, pp. 107-20.

Hymes, Del. 1981a. Breakthrough into Performance. In "In Vain I Tried to Tell You": Essays in Native American Ethnopoetics. Philadelphia: University of Pennsylvania, pp. 118-41.

Hymes, Del. 1981b. The 'Wife' Who 'Goes Out' like a Man. In "In Vain I Tried to Tell You": Essays in Native American Ethnopoetics. Philadelphia: University of Pennsylvania, pp. 274-308.

Irvin, Dorothy. 1977. The Joseph and Moses Stories as Narrative in the Light of Ancient Near Eastern Narrative. In Israelite and Judaean History. Edited by John H. Hayes and J. Maxwell Miller. Philadelphia: Westminster, pp. 180-209.

Jason, Heda. 1984. The Fairytale of the Active Heroine: An Outline for Discussion. In Le Conte, Pourquoi, Comment? Edited by G. Galame-Griaule, V. Görög-Karady and M. Chiche. Paris: Centre National de la Recherche Scientifique, pp. 79-97.

Joyce, Paul M. 1989. Divine Initiative and Human Response in Ezekiel. JSOT Supp. 51; Sheffield: JSOT Press.

King, Philip J., and Lawrence E. Stager. 2001. Life in Biblical Israel. Louisville: Westminster John Knox.

Kirshenblatt-Gimblett, Barbara. 1973. Toward a Theory of Proverb Meaning. Proverbium 22: 821-27.

Kselman, Jon R. 1978. The Recovery of Poetic Fragments from the Pentateuchal Priestly Source. Journal of Biblical Literature 97: 161-73. [CrossRef] 
Lester, G. Brooke. 2015. Daniel Evokes Isaiah. Allusive Characterization of Foreign Rule in theHebrew-Aramaic Book of Daniel. London: Bloomsbury T \& T Clark.

Lewis, Theodore J. 2016. Art and Iconography. Representing Yahwistic Divinity. In The Wiley Blackwell Companion to Ancient Israel. Edited by Susan Niditch. Chichester: Wiley Blackwell, pp. 510-33.

Lindars, Barnabas. 1965. Ezekiel and Individual Responsibility. Vetus Testamentum 15: 452-67. [CrossRef]

Lord, Albert Bates. 1968. The Singer of Tales. New York: Atheneum.

Mieder, Wolfgang. 2008. "Proverbs Speak Louder than Words": Folk Wisdom in Art, Culture, Folklore, History, Literature, and Mass Media. New York: Lang.

Miller, Patrick D. 1970. Animal Names as Designations in Ugaritic and Hebrew. Ugarit-Forschungen 2: 177-86.

Miller, Robert D., II. 2011. Oral Tradition in Ancient Israel. Eugene: Cascade Books.

Mills, Margaret. 1990. Domains of Folkloristic Concern: The Interpretation of Scripture. In Text and Tradition. Semeia Studies; Edited by Susan Niditch. Atlanta: Scholars Press, pp. 231-41.

Milne, Pamela. 1988. Vladimir Propp and the Study of Structure in Hebrew Biblical Narrative. Sheffield: Almond Press.

Nagy, Gregory. 1996. Homeric Questions. Austin: University of Texas Press.

Niditch, Susan. 1987. Underdogs and Tricksters: A Prelude to Biblical Folklore. San Francisco: Harper and Row.

Niditch, Susan. 1993. Folklore and the Hebrew Bible. Minneapolis: Fortress.

Niditch, Susan. 1996. Oral World and Written Word. Ancient Israelite Literature. Louisville: Westminster John Knox Press.

Niditch, Susan. 2008. "My Brother Esau Is a Hairy Man": Hair and Identity in Ancient Israel. Oxford: Oxford University Press.

Niditch, Susan. 2015. The Responsive Self. Personal Religion in Biblical Literature of the Neo-Babylonian and Persian Periods. New Haven: Yale University Press.

Niditch, Susan, and Robert Doran. 1990. The Success Story of the Wise Courtier. Journal of Biblical Literature 96: 179-93. [CrossRef]

O'Keeffe, Katherine O'Brien. 1990. Visible Song: Transitional Literacy in Old English Verse. Cambridge: Cambridge University Press.

Olrik, Axel. 1965. Epic Laws of Folk Narrative. In The Study of Folklore. Edited by Alan Dundes. Englewood Cliffs: Prentice Hall, pp. 129-41.

Person, Raymond F., Jr. 1998. The Ancient Israelite Scribe as Performer. Journal of Biblical Literature 117: 601-9. [CrossRef]

Person, Raymond F., Jr., and Robert Rezetko. 2016. Introduction. In Empirical Models Challenging Biblical Criticism. Edited by Raymond E. Person Jr. and Robert Rezetko. Atlanta: SBL Press, pp. 1-35.

Polak, Frank H. 1998. The Oral and the Written: Syntax, Stylistics and the Development of Biblical Prose Narrative. Journal of Near Eastern Studies 26: 59-105.

Polak, Frank H. 2016. Oral Platform and Language Usage in the Abraham Narrative. In The Formation of the Pentateuch. Bridging the Academic Cultures of Europe, Israel, and North America. Edited by Jan C. Gertz, Bernard M. Levinson, Dalit Rom-Shiloni and Konrad Schmid. Tübingen: Mohr Siebeck, pp. 405-42.

Prahlad, Sw Anand. 2005. Getting Happy: An Ethnographic Memoir. Journal of American Folklore 118: 21-44. [CrossRef]

Propp, Vladimir. 1960. The Morphology of the Folktale. Austin: University of Texas Press.

Propp, Vladimir. 1984. Theory and History of Folktales. Translated by A. Martin, and R. Martin. Edited by A. Liberman. Theory and History of Literature 5; Minneapolis: University of Minnesota Press.

Reventlow, Henning Graf. 2010. History of Biblical Interpretation, Vol. 4-From the Enlightenment to the Twentieth Century. Translated by Leo G. Purdue. Atlanta: Society of Biblical Literature.

Rölleke, Heinz. 1991. New Results of Research on Grimms' Fairy Tales. In The Brothers Grimm and Folktales. Edited by James M. McGlathery. Urbana and Chicago: University of Illinois Press, pp. 101-11.

Roy, Carrie, and Tim Frandy. 2013. Examining Augmented reality as a Platform for Situated Ethnography through the Lens of the ARIS Wisconsin Uprising Game. Journal of American Folklore 126: 70-80. [CrossRef]

Sasson, Jack. 1979. Ruth: A Translation with a Philological Formalist-Folklorist Interpretation. Baltimore: Johns Hopkins University Press.

Bernd U. Schipper, and D. Andrew Teeter, eds. 2013. Wisdom and Torah. The Reception of 'Torah' in the Wisdom Literature of the Second Temple Period. Supp. JSJ 163; Leiden: Brill.

Schmidt, Hans. 1907. Jona: Eine Untersuchung zur Vergleichenden Religionsgeschichte. Göttingen: Vandenhoeck und Ruprecht. 
Schniedewind, William M. 2004. How the Bible Became a Book: The Textualization of Ancient Israel. Cambridge: Cambridge University Press.

Siker, Jeffrey S. 2017. Liquid Scripture. Bible in a Digital World. Minneapolis: Fortress Press.

Sklar, Deidre. 2005. The Football of Words: A Reverie on Walking with Nuestra Señora de Guadalupe. Journal of American Folklore 118: 9-20. [CrossRef]

Stager, Lawrence E. 1989. The Song of Deborah. Why Some Tribes Answered the Call and Others Did Not. Biblical Archaeology Review 15: 51-64.

Stavrakopoulu, Francesca. 2016. Religion at Home. The Materiality of Practice. In The Wiley Blackwell Companion to Ancient Israel. Edited by Susan Niditch. Chichester: Wiley Blackwell, pp. 347-65.

Tedlock, Dennis. 1990. From Voice and Ear to Hand and Eye. Journal of American Folklore 103: 133-56. [CrossRef]

Teeter, Andrew. 2013. The Hebrew Bible and/as Second Temple Literature: Methodological Reflections. Dead Sea Discoveries 20: 349-77. [CrossRef]

Thatcher, Tom, Chris Keith, Raymond F. Person Jr., and Elsie R. Stern, eds. 2017. The Dictionary of the Bible and Ancient Media. London and Oxford: Bloomsbury.

Thompson, Stith. 1955-1958. The Motif-Index of Folk Literature. 6 vols. Bloomington: Indiana University Press.

Thompson, Stith. 1973. The Types of the Folktale. FFC 184; Helsinki: Suomalainen Tiedeakatemia.

Tucker, Gene M. 1971. Form-Criticism of the Old Testament. Philadelphia: Fortress.

Urbrock, William J. 1976. Oral Antecedents to Job: A Survey of Formulas and Formula Systems. Semeia 5: 111-37.

Von Rad, Gerhard. 1961. Genesis: A Commentary. Philadelphia: Westminster, Originally published 1956 in Germany.

Wellhausen, Julius. 1965. Prolegomena to the History of Ancient Israel. Translated by Menzies, and Black. Cleveland and New York: World Publishing Company. First published 1878.

Westermann, Claus. 1984-1986. Genesis. A Commentary. 3 vols. Minneapolis: Augsburg.

Wilson, Robert R. 1980. Prophecy and Society in Ancient Israel. Philadelphia: Fortress.

Yoshimura, Ayako. 2015. To Believe and Not to Believe: A Native Ethnography of Kanashibari in Japan. Journal of American Folklore 128: 146-78. [CrossRef]

Zakovitch, Yair. 1981. From Oral to Written Tale in the Bible (in Hebrew). Jerusalem Studies in Jewish Folklore 1: 9-43. Zipes, Jack. 1991. Dreams of a Better Bourgeois Life: The Psychosocial Origins of the Grimms' Tales. In The Brothers Grimm and Folktales. Edited by James M. McGlathery. Urbana and Chicago: University of Illinois Press, pp. 205-19.

(C) 2018 by the author. Licensee MDPI, Basel, Switzerland. This article is an open access article distributed under the terms and conditions of the Creative Commons Attribution (CC BY) license (http://creativecommons.org/licenses/by/4.0/). 